\title{
Sporozoite immunization of human volunteers under chemoprophylaxis induces functional antibodies against pre-erythrocytic stages of Plasmodium falciparum
}

Marije C Behet ${ }^{1}$, Lander Foquet ${ }^{2}$, Geert-Jan van Gemert ${ }^{1}$, Else M Bijker ${ }^{1}$, Philip Meuleman², Geert Leroux-Roels ${ }^{2}$, Cornelus C Hermsen ${ }^{1}$, Anja Scholzen ${ }^{1}$ and Robert W Sauerwein ${ }^{1 *}$

\begin{abstract}
Background: Long-lasting and sterile protective immunity against Plasmodium falciparum can be achieved by immunization of malaria-naive human volunteers under chloroquine prophylaxis with sporozoites delivered by mosquito bites (CPS-immunization). Protection is mediated by sporozoite/liver-stage immunity. In this study, the capacity of CPS-induced antibodies to interfere with sporozoite functionality and development was explored.

Methods: IgG was purified from plasma samples obtained before and after CPS-immunization from two separate clinical trials. The functionality of these antibodies was assessed in vitro in gliding and human hepatocyte traversal assays, and in vivo in a human liver-chimeric mouse model.

Results: Whereas pre-treatment of sporozoites with $2 \mathrm{mg} / \mathrm{ml} \mathrm{lgG}$ in the majority of the volunteers did not have an effect on in vitro sporozoite gliding motility, CPS-induced IgG showed a distinct inhibitory effect in the sporozoite in vitro traversal assay. Pre-treatment of $P$. falciparum sporozoites with post-immunization IgG significantly inhibited sporozoite traversal through hepatocytes in 9/9 samples when using 10 and $1 \mathrm{mg} / \mathrm{ml} \operatorname{lgG}$, and was dose-dependent, resulting in an average $16 \%$ and $37 \%$ reduction with $1 \mathrm{mg} / \mathrm{ml} \mathrm{lgG}(p=0.003)$ and $10 \mathrm{mg} / \mathrm{ml}$ $\lg (p=0.002)$, respectively. In vivo, CPS-induced IgG reduced liver-stage infection and/or development after a mosquito infection in the human liver-chimeric mouse model by $91.05 \%$ when comparing 11 mice receiving post-immunization $\lg G$ to 11 mice receiving pre-immunization $\lg G(p=0.0008)$.

Conclusions: It is demonstrated for the first time that CPS-immunization induces functional antibodies against P. falciparum sporozoites, which are able to reduce parasite-host cell interaction by inhibiting parasite traversal and liver-stage infection. These data highlight the functional contribution of antibody responses to pre-erythrocytic immunity after whole-parasite immunization against $P$. falciparum malaria.
\end{abstract}

Keywords: Malaria, Plasmodium falciparum, Sporozoites, Liver-stage, Immunization, CPS, CHMI, Inhibitory antibodies, Human liver-uPA-SCID mouse model

\section{Background}

Malaria is caused by mosquito-transmitted protozoan Plasmodium falciparum parasites with a complex multistage life cycle in the human host. When $P$. falciparum-infected Anopheles mosquitoes probe for blood, sporozoites are deposited in the skin, move by circular locomotion

\footnotetext{
* Correspondence: Robert.Sauerwein@radboudumc.nl

${ }^{1}$ Radboud University Medical Center, Department of Medical Microbiology, Geert Grooteplein 28, Microbiology 268, Nijmegen, HB 6500, The Netherlands Full list of author information is available at the end of the article
}

(gliding) [1], and traverse cell barriers by breaching host cell membranes [2]. When sporozoites have reached the liver via the blood circulation, they first cross the sinusoidal barrier, traverse through and eventually invade hepatocytes [2,3]. Previous studies have demonstrated the importance of $P$. falciparum sporozoite gliding motility for invasion of a hepatocyte [4,5]. Moreover, cell traversal has been shown to be important for the progression of sporozoites to the liver and thus, enhancement of 
successful infection [3,6-8]. Subsequent liver-stage development is completed by merozoite release into the bloodstream and invasion of erythrocytes (asexual bloodstages) [9].

Immunity against malaria can be naturally acquired in individuals living in malaria-endemic areas, however, only after continuous exposure to the parasite, and appears to wane in the absence of ongoing $P$. falciparum exposure [10]. Historic passive transfer studies have demonstrated a key role for antibodies in controlling blood-stage parasites during natural $P$. falciparum infection and reducing clinical symptoms of malaria [11-13], as confirmed in animal models of malaria [14-16]. Although antibodies are crucial in controlling bloodstages, naturally acquired immunity never results in complete parasite elimination.

Generating long-lasting and sterilizing immunity against malaria with pre-erythrocytic subunit vaccines, has only had limited success. The RTS,S subunit vaccine, to date the only most advanced malaria vaccine candidate tested in Phase III clinical trials, is based on P. falciparum circumsporozoite protein (CSP), a major sporozoite surface protein [17]. The RTS,S vaccine has been shown to elicit strong CSP-specific antibodies and to induce protection in the majority of the volunteers in a CHMI model upon infectious mosquito bite challenge [18-21]. However, 4/5 and 5/9 protected volunteers developed delayed parasitaemia upon re-challenge with infectious mosquito bites $\sim$ six or five months after the initial challenge, respectively [21,22]. Additionally, RTS,S vaccination only confers modest protection in the field [23-26]. Immunization with other subunit vaccines, for instance with the sporozoite surface protein 2 (a homolog for P. falciparum thrombospondin-related adhesion protein (TRAP)) which is expressed on both the surface of sporozoites [27,28] and within infected hepatocytes [28], induced only partial protection in mice, but complete protection when given together with CSP [29]. However, Phase I/IIa clinical trials in which humans were immunized with RTS, S/TRAP failed to provide protection in the majority of volunteers (unpublished data, as written by [30]). Moreover, immunization of humans with a recombinant liverstage antigen-1 (LSA-1)-based vaccine elicited high antibody titers, but did also not protect against $P$. falciparum infection [31].

While the induction of sterile immunity with subunit vaccines has been shown to be difficult, sterile immunity against malaria can be achieved experimentally by whole-parasite immunization with attenuated sporozoites in animal models and human volunteers, targeting the sporozoite/liver-stage parasites (pre-erythrocytic stages). As early as the 1960s, it was shown that sterile protective immunity can be induced in animals and humans by immunization with Plasmodium sporozoites attenuated by gamma irradiation (RAS) and delivered by P. falciparum-infected mosquito bites [32-34]. Sera from RAS-immunized subjects were able to reduce sporozoite invasion into hepatocytes, as shown in both animal [35,36] and human models of malaria [37-39]. This immunization approach, however, requires a minimum of 1,000 bites from irradiated mosquitoes to induce sterilizing immunity in humans. Therefore, more studies to other potential immunization methods have been conducted. Very recently, it has been demonstrated that intravenous immunization of humans with a radiationattenuated and cryopreserved $P$. falciparum sporozoite vaccine can also induce protection against $P$. falciparum malaria [40]. In vitro invasion experiments with hepatoma cells and sera from volunteers protected after 4-5 immunization doses revealed that immunization-induced antibodies were able to inhibit in vitro sporozoite invasion [40]. However, to circumvent the need for irradiation of parasites, another whole-parasite vaccination approach has been developed, to be specific the genetically engineered and attenuated parasites (GAP). Passive immunization of naive mice with pooled serum from mice immunized i.v. with Plasmodium yoelii-GAP one day before mosquito bite challenge, reduced the liver parasite burden by 48 hours after infection [41]. Exposure of human volunteers to $\sim 5$ bites from mosquitoes infected with a first generation of P. falciparum GAP (PfGAP), followed by a high-dose exposure to 200 PfGAP-infected mosquito bites, led to breakthrough infection in one out of six volunteers, consisting of breakthrough PfGAP-parasites [42]. While this Phase I study was not safe and therefore not successful, plasma from volunteers obtained three months after high-dose exposure could efficiently block in vitro hepatoma cell invasion by $P$. falciparum sporozoites [43].

Next to the RAS and GAP whole-parasite vaccination approaches, a highly efficient immunization regimen based on controlled human malaria infection (CHMI) that induces long-lasting sterile immunity in malaria-naive individuals has recently been established: volunteers are exposed to $\sim 45$ wild type $P$. falciparum-infected mosquito bites, while receiving a prophylactic regimen of chloroquine (ChemoProphylaxis and Sporozoites, CPS) [44,45]. CPS-immunization allows full liver-stage maturation and development of early asexual blood-stage parasites, however, it induces protection specifically targeting pre-erythrocytic, but not blood-stages [46]. In previous CPS-immunization studies, cellular responses to both blood-stage parasites and sporozoites were found $[45,47]$. Antibodies targeting the cell-free sporozoites may interfere with migration and invasion of hepatocytes, and thus lower the initial liver parasite load and complement T-cell mediated protection. Analysis of antibody responses by $P$. falciparum protein-microarray identified two pre- 
erythrocytic antigens i.e. CSP and LSA- 1 as the two proteins predominantly recognized after CPS-immunization [48]. Moreover, efficient induction of memory B-cells and antibodies was found to classical pre-erythrocytic antigens, to be specific CSP and LSA-1 (Nahrendorf and Scholzen et al., manuscript in preparation). While the induction of antibodies by CPS-immunization has been demonstrated, their functional activity against sporozoite/ liver-stage parasites has not yet been established. This study, therefore, focused on the possible functional contribution of antibodies to pre-erythrocytic protective immunity after CPS-immunization.

\section{Methods}

\section{Study design and plasma sample collection}

Citrated plasma samples were collected during two clinical CPS-immunization trials approved by the Central Committee for Research Involving Human Subjects of The Netherlands (Study 1 [44], ClinicalTrials.gov number NCT00442377; CCMO NL24193.091.09, and Study 2 [46], ClinicalTrials.gov number NCT01236612; CCMO NL34273.091.10). In both studies, healthy malaria-naive Dutch volunteers were immunized three times at monthly intervals by exposure to $12-15 P$. falciparuminfected mosquito bites, while receiving chloroquine prophylaxis. All subjects provided written informed consent before screening and the study team complied with the Declaration of Helsinki and Good Clinical Practice. The following plasma samples, collected before (pre) and after CPS-immunization (post), were selected for IgG purification based on availability: ten volunteers from Study 1 and three from Study 2 protected against sporozoite challenge infection and another three volunteers from Study 2 challenged with blood-stages. For the latter three, their protection status upon sporozoite challenge is therefore unknown.

\section{IgG purification from citrated plasma samples}

IgG purification from 3-8 $\mathrm{ml}$ plasma samples was performed using a $5 \mathrm{ml}$ HiTrap Protein G HP column (Amersham Biosciences) according to manufacturer's instructions and IgG was taken up in phosphate buffered saline (PBS, GIBCO). IgG concentrations were determined by a NanoDrop spectrophotometer (NanoDrop Technologies, NanoDrop program 1000 version 3.8.2.). For Study 1, due to limited plasma availability, IgG samples from two volunteers each were pooled, resulting in five pools of two volunteers. For Study 2, IgG samples from six individual CPS-immunized volunteers were available.

\section{Generation of $P$. falciparum sporozoites}

Plasmodium falciparum NF54 asexual and sexual blood stages were cultured in a semi-automated culture system
[49-51]. Sporozoites were produced by feeding female Anopheles stephensi mosquitoes using standard membrane feeding of cultured gametocytes [52]. For in vitro assays, salivary glands were hand dissected, collected in Leibovitz culture medium (Sigma Aldrich) supplemented with $10 \%$ foetal bovine serum (FBS, GIBCO), homogenized in a homemade glass grinder. Sporozoites were counted in a Bürker-Türk counting chamber using phasecontrast microscopy.

\section{Gliding assay}

Gliding assays were performed in eight-chamber glass Lab-Tek chamber slides (Nalgene, Nunc) pre-coated with $25 \mu \mathrm{g} / \mathrm{ml}$ monoclonal anti-CSP (3SP2, [53]) to capture shed $P$. falciparum circumsporozoite protein. Sporozoites were pre-incubated in duplicate with $2 \mathrm{mg} / \mathrm{ml}$ pre- or post-immunization IgG (due to limited plasma/ IgG availability) in the presence of $10 \%$ FBS for $30 \mathrm{~min}$ on ice and then sporozoite/IgG suspension (30,000 spz/well) was added to each well. After $90 \mathrm{~min}$ of incubation at $37^{\circ} \mathrm{C}$ in $5 \% \mathrm{CO}_{2}$, gliding trails were fixed with $4 \%$ paraformaldehyde (PFA) for $20 \mathrm{~min}$ at room temperature (RT). Each well was washed twice with PBS, blocked with $10 \%$ FBS in PBS for 20 min at RT and washed again. Gliding trails were visualized with $10 \mu \mathrm{g} / \mathrm{ml}$ anti-CSP-FITC in $10 \% \mathrm{FBS}$ in PBS, incubated for $60 \mathrm{~min}$ in the dark at RT, washed and mounted with Fluoromount-G (Southern Biotech) and $24 \times 50 \mathrm{~mm}$ cover glasses (VWR International). The number of gliding trails was counted per 280 fields of view (per well) at an enlargement of $1,000 \times$ with oil immersion.

\section{Traversal assay}

The functional capacity of CPS-induced antibodies to inhibit sporozoite traversal through human hepatocytes in vitro was studied using an optimized flow cytometry based version (Behet et al., manuscript in preparation) of the dextran incorporation assay [2,54]. Only cells traversed by sporozoites and, therefore, wounded, incorporate dextran and the percent of dextran-positive cells can be quantified with flow cytometry.

The HC-04 hepatocyte cell line (Homo sapiens HC-04, MRA-975, deposited by Jetsumon Sattabongkot [55]) was obtained through the MR4 as part of the BEI Resources Repository (NIAID, NIH). Cells were cultured in HC-04 cell culture medium, containing equal volumes of F-12 Nutrient Mixture (GIBCO) and Minimal Essential Medium (GIBCO) supplemented with 10\% FBS (GIBCO) and $1 \%$ penicillin/streptomycin (GIBCO), at $37^{\circ} \mathrm{C}$ in an atmosphere of $5 \% \mathrm{CO}_{2}$.

Plasmodium falciparum sporozoites were pre-incubated with $10 \mathrm{mg} / \mathrm{ml}$ or $1 \mathrm{mg} / \mathrm{ml}$ IgG for $30 \mathrm{~min}$ on ice. Data from 2 pre-immunization IgG samples from Study 1 were lost for technical reasons. Sporozoites pre-treated with $1.25 \mu \mathrm{g} / \mathrm{ml}$ of the mycotoxin cytochalasin D [56] served as 
a positive control resulting in a mean traversal inhibition of $93.1 \%$ and non-infected cells incubated with dextran served as a background control.

Sporozoites $\left(5.10^{4}\right)$ were added to 96 -well plates containing monolayers of $5.10^{4} \mathrm{HC}-04$ hepatocytes in the presence of $0.5 \mathrm{mg} / \mathrm{ml}$ fixable tetramethylrhodamine dextran (10,000 MW, D1817, Invitrogen) in duplicates or triplicates, centrifuged at 3,000 RPM for $10 \mathrm{~min}$ at RT with a low brake (Eppendorf Centrifuge $5810 \mathrm{R}$ ) and incubated for $2 \mathrm{~h}$ at $37^{\circ} \mathrm{C}$ in $5 \% \mathrm{CO}_{2}$. After incubation, wells were gently washed three times with PBS to remove extracellular dextran, trypsinized with $0.05 \%$ Trypsin-EDTA (GIBCO) for $5 \mathrm{~min}$ at RT, taken up in $10 \% \mathrm{FBS}$ in PBS, and centrifuged at 3,600 RPM for 5 min at RT (Eppendorf Centrifuge 5415 D). Cells were re-suspended in 1\% PFA in PBS and stored at $4^{\circ} \mathrm{C}$ in the dark until flow cytometric analysis on an ADP Cyan flow cytometer (Beckman Coulter). Sporozoite traversal was corrected for background dextran incorporation and the percent inhibition of traversal was calculated as follows: 1 - (average\% dextran-positive cells in post-immunization IgG cultures/ average $\%$ dextran-positive cells in pre-immunization IgG cultures) $\times 100 \%$.

\section{Passive immunization of human liver-chimeric mice and sporozoite challenge}

Human liver-chimeric mice over-expressing urokinasetype plasminogen activator on a severe combined immunodeficiency background $\left(\mathrm{uPA}^{+/+}\right.$-SCID mice) were generated as previously described $[57,58]$. Cryopreserved primary human hepatocytes $\left( \pm 1.10^{6}\right.$ cells/mouse, all from the same donor and purchased from BD Gentest (Erembodegem, Belgium) were injected in the spleens of $\mathrm{uPA}^{+/+}$-SCID mice within two weeks after birth [57]. Human albumin levels were measured at different time points after transplantation by using the Human Albumin ELISA Quantitation kit (Bethyl Laboratories Inc., Montgomery, TX). Mice with human albumin levels of $>2 \mathrm{mg} / \mathrm{ml}$ were considered successfully engrafted and used for infection studies. All procedures were approved by the Animal Ethics Committee of the Faculty of Medicine and Health Sciences of the Ghent University (ECD 11/03).

The day before $P$. falciparum infection by mosquito bites, human liver-chimeric mice were injected intraperitoneally with $10 \mathrm{mg}$ of post-immunization IgG from five sets of two CPS-immunized volunteers per pool (Study 1) and six CPS-immunized volunteers (Study 2). Each mouse was injected with one IgG sample, and mice injected with preimmunization IgG served as controls. Mice were challenged by exposure to $P$. falciparum-infected mosquito bites as previously described [58]. Briefly, the abdomen and chest of mice were shaved with electric clippers and subsequently, mice were positioned on a cardboard box containing $20 \mathrm{P}$. falciparum-infected mosquitoes (one mouse per box) and exposed for 20 minutes to infectious mosquito bites. Successful blood feeding (median: 16 mosquitoes) and sporozoite presence (100\%) was confirmed by mosquito dissection after the challenge experiment $[59,60]$.

Due to limited availability of liver-chimeric mice, each IgG sample was injected in one mouse. The relatively wide range in liver load in control mice receiving only infectious mosquito bites as described previously [58,61], was also reflected in the present study in the group of mice receiving pre-immunization IgG. This precludes paired analysis of mice receiving pre- and post-immunization IgG from the same donor, and only allows to compare the preand post-immunization groups at group level.

\section{Isolation of DNA and quantification of $P$. falciparum and human hepatocyte DNA}

Isolation of liver DNA and quantification of $P$. falciparum and human hepatocyte DNA was performed as previously described [58]. Briefly, five days after sporozoite challenge mice were maximally bled and sacrificed by cervical dislocation. The removed livers were cut into 12 standardized sections and stored in RNALater (Ambion) at $4^{\circ} \mathrm{C}$ until analysis. For DNA extraction, $25 \mathrm{mg}( \pm 0.1 \mathrm{mg})$ liver tissue was taken from each section and P. falciparum, mouse and human hepatocyte DNA levels were quantified in a total of $300 \mathrm{mg}$ of liver tissue (12 sections $\times 25$ mg; $\sim 25 \%$ of total liver) using a highly sensitive qPCR assay, targeting Pf18SRNA and mouse and human prostaglandin E receptor (PTGER2) genes, respectively [58,62]. The quantification of the relative amount of human and mouse hepatocytes in mixed liver tissues allowed us to assess the repopulation of chimeric mouse livers with human hepatocytes, and thus to express $P$. falciparum liver infection as a number of parasites per $10^{6}$ human hepatocytes [58,63]. DNA extracts from titrated samples of ring-stage $P$. falciparum-infected erythrocytes that were spiked with extracted DNA from a uninfected humanized liver, were used for preparation of $P$. falciparum standard curves. Standard curves were prepared by DNA extraction from a titration of defined numbers of human peripheral mononuclear cells (PBMCs) and mouse splenocytes. Percentage calculation was verified by making various ratios of mouse and human DNA extracts [58].

\section{Statistical analysis}

Statistical analysis was performed using GraphPad Prism software version 5 (GraphPad Software Inc., California, USA). For analysis of data of traversal experiments, differences between the percentage of dextran-positive cells in pre- and post-immunization samples were tested using the paired Student's t-test. Statistical analysis of humanized mouse data was performed using the nonpaired, non-parametric Mann Whitney U-test. A p-value of $<0.05$ was considered significant. 


\section{Results}

Sporozoite gliding motility is not consistently reduced by low IgG concentrations of CPS-induced antibodies

To explore the capacity of CPS-induced antibodies to interfere with in vitro sporozoite gliding motility, sporozoite gliding trails produced by $P$. falciparum sporozoites pre-incubated with $2 \mathrm{mg} / \mathrm{ml}$ of either pre- or postimmunization IgG from five pools of two volunteers each (Study 1) or individual IgG samples from six CPSimmunized volunteers (Study 2), were counted by microscopy. In vitro sporozoite gliding motility tested was highly variable, not only between volunteers, but also between replicates (Figure 1). In the presence of $2 \mathrm{mg} / \mathrm{ml}$ postimmunization IgG, the number of gliding trails was reduced in 3 out of 11 samples ( $\mathrm{n}=1$ from Study 1 (Pool 5), and $n=2$ from Study 2 (Volunteers 1 and 3 ); Figure 1 ), but in the majority of the volunteers no effect could be observed.

\section{Sporozoite traversal is dose-dependently inhibited by CPS-induced antibodies}

Subsequently, the inhibitory activity of immunizationinduced antibodies on in vitro hepatocyte traversal by sporozoites was investigated. The percentage cells traversed by sporozoites pre-incubated with two concentrations (1 or $10 \mathrm{mg} / \mathrm{ml}$ ) of either pre- or post-immunization IgG from three pools of two CPS-immunized volunteers each (Study 1) and six individual CPS-immunized volunteers (Study 2), was determined by flow cytometry (Figure 2A and Additional file 1A and B). Pre-treatment of sporozoites with $10 \mathrm{mg} / \mathrm{ml}$ post-immunization IgG from both Study 1 and Study 2 lead to a statistically significant reduction in in vitro hepatocyte traversal for all volunteers, compared to pre-immunization IgG treatment (Figure 2B and C; Study 1, p = 0.047; Study 2, p = 0.007). The mean percent traversal inhibition by $10 \mathrm{mg} / \mathrm{ml}$ IgG was $36.7 \%(p=0.002 ; 50.5 \%$ (range $31.4-70.5 \%)$ and $29.8 \%$ (range 9.7-54.6\%) for Study 1 and 2, respectively). Traversal inhibition was concentration-dependent, and significantly higher for $10 \mathrm{mg} / \mathrm{ml}$ compared to $1 \mathrm{mg} / \mathrm{ml} \mathrm{IgG}$ ( $p=0.005$; Figure 2D). Nevertheless, even as little as 1 $\mathrm{mg} / \mathrm{ml}$ post-immunization IgG resulted in a significant inhibition of sporozoite traversal ( $\mathrm{p}=0.003$ ) of $16.2 \%$ (mean; range 1.6-45.5\%; Figure 1D). Although the percentage of traversed cells varied between experiments with individual mosquito and sporozoite batches (Figure 2B and $C$ ), the variability between duplicate/triplicate measurements within each experiment for each IgG sample was very low (Additional file $1 \mathrm{~A}$ and $\mathrm{B} ; 1 \mathrm{mg} / \mathrm{ml} \mathrm{IgG}$ and $10 \mathrm{mg} / \mathrm{ml}$ IgG, respectively).

\section{Functional CPS-induced antibodies inhibit in vivo sporozoite infection of the liver}

Finally, it was investigated whether in vitro inhibitory activity of CPS-induced IgG on sporozoite traversal would translate into inhibition of sporozoite infection of and/or development in the liver in vivo, using human liver-chimeric mice infected with $P$. falciparum sporozoites by mosquito bites. In two independent experiments, mice were passively immunized with $10 \mathrm{mg}$ of either pre- or post-immunization IgG from five pools of two volunteers each (Study 1) and six individual CPSimmunized volunteers (Study 2) the day before challenge infection. qPCR analysis was performed on liver sections

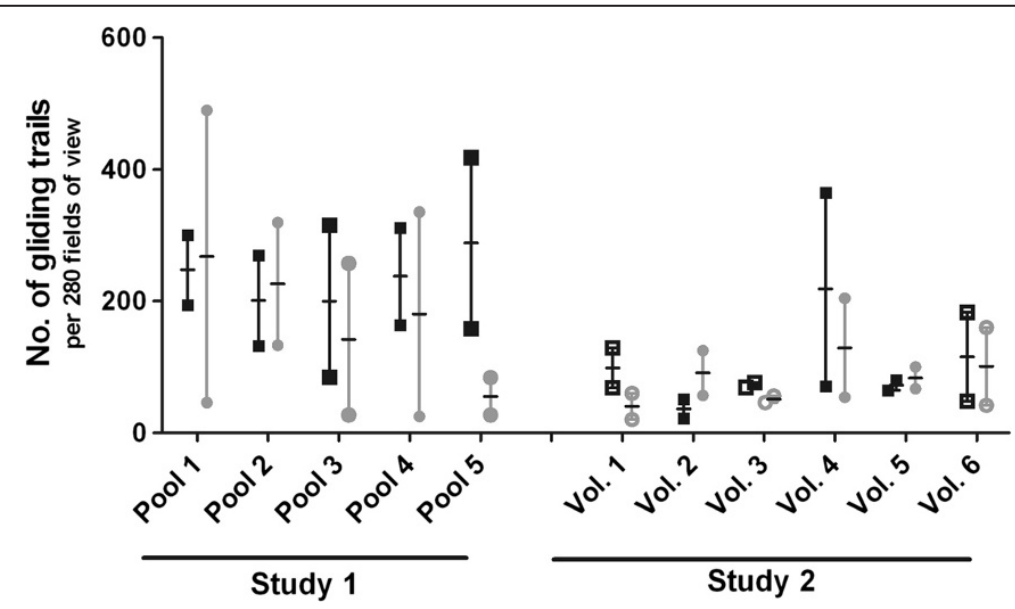

Figure 1 Effect of CPS-induced IgG on in vitro sporozoite gliding motility. The number of sporozoite gliding trails produced by sporozoites incubated with $2 \mathrm{mg} / \mathrm{ml}$ lgG was counted in 280 fields per well at an enlargement of 1,000x with oil immersion. Incubations were performed in duplicates and data are expressed as median with range. Pre- or post-immunization lgG samples from five pools of two volunteers each (Study 1) or from six volunteers (Study 2), immunized by ChemoProphylaxis and Sporozoites immunization (CPS), were tested in 3 independent experiments in duplicate. Black squares and grey circles represent the number of gliding trails produced by sporozoites incubated with pre- or post-immunization IgG, respectively. Filled symbols show volunteers protected against mosquito challenge. Open symbols represent volunteers with unknown protection status regarding mosquito challenge (blood-stage challenged). 


\section{A}

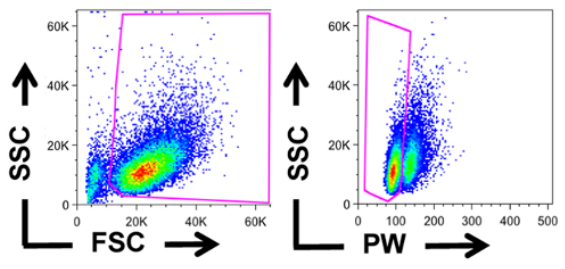

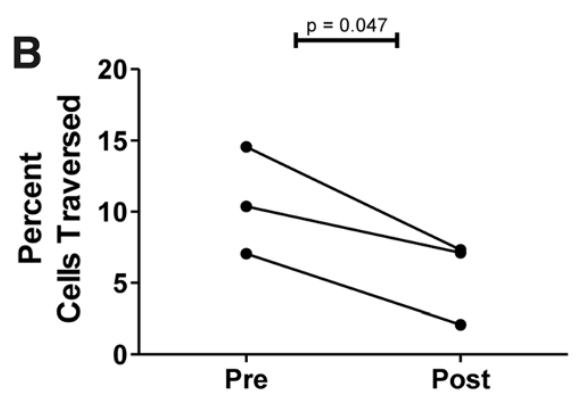

Dextran

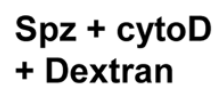

\section{Dextran only}
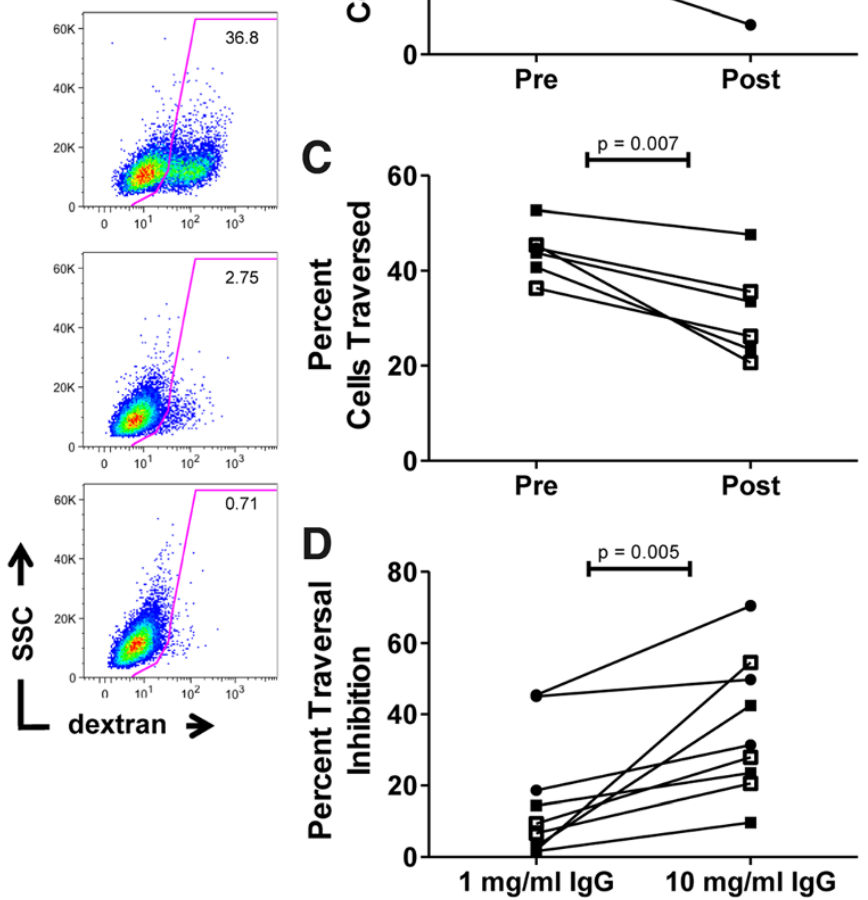

Figure 2 Effect of CPS-induced IgG on in vitro hepatocyte traversal. (A) The proportion of traversed (wounded) cells was determined by flow cytometric analysis, after gating out debris and doublets. Sporozoites with dextran only were used as a positive control and sporozoites pre-treated with cytochalasin D (cytoD) and dextran, as a negative control. Cells incubated with dextran only were used to correct for background. (B) Sporozoites were pre-incubated with $10 \mathrm{mg} / \mathrm{ml}$ pre- or post-immunization lgG from three pools of two volunteers each (Study 1) or (C) from six individual volunteers (Study 2), all of which underwent ChemoProphylaxis and Sporozoites immunization (CPS). Samples were tested in 4 experiments with 3 mosquito batches, in duplicate or triplicates. (D) The percentage inhibition of traversal was calculated for post- compared to pre-immunization IgG for each pool/volunteer at a concentration of either 1 or $10 \mathrm{mg} / \mathrm{ml}$. Data are shown as the mean of duplicate or triplicate measurements, and presented as circles or squares for Study 1 and 2, respectively. Filled symbols show volunteers protected against mosquito challenge. Open symbols represent volunteers with unknown protection status regarding mosquito challenge (blood-stage challenged). Differences between pre- and post-immunization lgG, and 1 and $10 \mathrm{mg} / \mathrm{ml} \mathrm{lgG}$ was tested using the paired Student's t-test.

from all mice to determine the liver parasite burden after five days to allow full liver-stage development of P. falciparum parasites. The two groups of mice receiving pre- or post-immunization IgG had comparable levels of repopulation with human hepatocytes and body weight, and there was no statistically significant difference in the number of mosquitoes fed on both groups of mice (Table 1), nor between the two experiments conducted.

Passive immunization of liver humanized $\mathrm{uPA}^{+/+}$-SCID mice with post-immunization IgG one day prior to mosquito bite challenge significantly reduced the number of infected hepatocytes by day 5 of infection (Table 1). The median number of liver sections positive for $P$. falciparum infection $\left(P f_{+}\right)$was significantly higher for mice injected with pre- (median $5 P f+$ liver sections, interquartile range
(IQR) 4-10) than with post-immunization IgG (median 3 $P f+$ liver sections, IQR 2-3; $\mathrm{p}=0.003$ ) and did not statistically differ between Study 1 and 2 samples. Additionally, the median number of $P$. falciparum parasites per million human hepatocytes in mice injected with either pre- or post-immunization IgG was 326.5 (IQR: 209.3- 354.5) and 29.2 (IQR: 19.30-60.90), respectively and did not differ between Study 1 and 2 samples. The reduction of the median liver load by post-immunization IgG was $91.05 \%$, comparing the two groups of mice $(\mathrm{n}=11$ each) receiving post-immunization or pre-immunization $\operatorname{IgG}(\mathrm{p}=0.0008)$.

\section{Discussion}

This study demonstrates for the first time that antibodies with inhibitory activity against pre-erythrocytic 
Table 1 Reduction of liver parasite burden by CPS-induced antibodies

\begin{tabular}{|c|c|c|c|c|c|c|c|c|c|}
\hline & $\begin{array}{l}\text { Mouse } \\
\text { ID }\end{array}$ & $\begin{array}{c}\text { lgG } \\
\text { sample ID }\end{array}$ & $\begin{array}{l}\text { Time } \\
\text { point }\end{array}$ & $\begin{array}{c}\text { Human } \\
\text { albumin levels } \\
(\mathrm{mg} / \mathrm{ml})\end{array}$ & $\begin{array}{l}\text { Proportion of } \\
\text { HuHEP } \\
\text { mouse in liver (\%) }\end{array}$ & $\begin{array}{l}\text { Weight } \\
\text { mice } \\
(g)\end{array}$ & $\begin{array}{c}\text { Number of } \\
\text { fed mosquitoes } \\
\text { (out of 20) }\end{array}$ & $\begin{array}{c}\text { Liver parasite } \\
\text { burden } \\
\text { (No. Pf/10^ } 6 \text { HuHEP) }\end{array}$ & $\begin{array}{c}\text { No. of } P f^{c} \text { positive } \\
\text { liver sections } \\
\text { (out of } 12 \text { ) }\end{array}$ \\
\hline \multicolumn{10}{|c|}{ Pre-CPS ${ }^{\mathrm{a}}$ IgG } \\
\hline \multirow[t]{5}{*}{ Study 1} & B730R & Pool 1 & Pre & 2,4 & 26,0 & 15,9 & 14 & 326,5 & 10 \\
\hline & K1596RL & Pool 2 & Pre & 2,6 & 37,2 & 11,5 & 19 & 209,3 & 5 \\
\hline & B749RL & Pool 3 & Pre & 3,0 & 39,7 & 12,1 & 17 & 77,2 & 5 \\
\hline & K1589R & Pool 4 & Pre & 4,0 & 33,0 & 12,5 & 14 & 280,1 & 11 \\
\hline & K1576 & Pool 5 & Pre & 3,1 & 35,0 & 12,2 & 20 & 373,0 & 10 \\
\hline \multicolumn{4}{|l|}{ Median } & 3,0 & 35,0 & 12,2 & 17 & 280,1 & 10 \\
\hline \multirow[t]{6}{*}{ Study 2} & K1630LR & Vol. $^{d} 1$ & Pre & 3,0 & 40,1 & 15,1 & 16 & 354,5 & 7 \\
\hline & B934R & Vol. 2 & Pre & 2,2 & 29,1 & 11,7 & 18 & 329,8 & 4 \\
\hline & B934LR & Vol. 3 & Pre & 2,6 & 37,7 & 12,8 & 17 & 37,6 & 3 \\
\hline & B934L & Vol. 4 & Pre & 1,7 & 28,5 & 9,6 & 12 & 463,1 & 4 \\
\hline & K1575 & Vol. 5 & Pre & 1,8 & 34,4 & 17,3 & 15 & 342,1 & 2 \\
\hline & B881R & Vol. 7 & Pre & 2,2 & 33,0 & 8,4 & 13 & 300,3 & 8 \\
\hline \multicolumn{4}{|l|}{ Median } & 2,2 & 33,7 & 12,3 & 16 & 336,0 & 4 \\
\hline \multicolumn{4}{|c|}{ Median Pre-CPS IgG Study 1 and 2: } & 2,6 & 34,4 & 12,2 & 16 & 326,5 & 5 \\
\hline \multicolumn{10}{|c|}{ Post-CPS IgG } \\
\hline \multirow[t]{5}{*}{ Study 1} & K1577L & Pool 1 & Post & 1,9 & 29,2 & 15 & 16 & 90,5 & 1 \\
\hline & K1540L & Pool 2 & Post & 2,6 & 31,6 & 12,6 & 18 & 13,1 & 3 \\
\hline & B733 & Pool 3 & Post & 5,2 & 40,8 & 6,7 & 16 & 46,4 & 2 \\
\hline & K1589 & Pool 4 & Post & 4,5 & 35,9 & 13,1 & 15 & 20,8 & 3 \\
\hline & B750L & Pool 5 & Post & 2,5 & 33,4 & 12,2 & 16 & 302,6 & 6 \\
\hline \multicolumn{4}{|l|}{ Median } & 2,6 & 33,4 & 12,6 & 16 & 46,4 & 3 \\
\hline \multirow[t]{6}{*}{ Study 2} & K1666L & Vol. 1 & Post & 4,6 & 41,0 & 15,7 & 14 & 37,1 & 3 \\
\hline & B934 & Vol. 2 & Post & 1,8 & 17,4 & 11,7 & 16 & 6,7 & 1 \\
\hline & B905 & Vol. 3 & Post & 4,2 & 41,2 & 12,7 & 18 & 28,3 & 2 \\
\hline & K1630L & Vol. 4 & Post & 1,7 & 21,2 & 14,6 & 14 & 60,9 & 2 \\
\hline & B865 & Vol. 5 & Post & 2,3 & 36,5 & 17,3 & 14 & 29,2 & 3 \\
\hline & K1683 & Vol. 7 & Post & 2,3 & 31,3 & 9,7 & 15 & 19,3 & 3 \\
\hline \multicolumn{4}{|l|}{ Median } & 2,3 & 33,9 & 13,7 & 15 & 28,8 & 3 \\
\hline \multicolumn{4}{|c|}{ Median Post-CPS IgG Study 1 and 2: } & 2,5 & 33,4 & 12,7 & 16 & 29,2 & 3 \\
\hline \multicolumn{4}{|c|}{$\begin{array}{l}\text { Significant difference Post- versus } \\
\text { Pre-CPS IgG }\end{array}$} & ns & ns & ns & ns & $p=0.0008$ & $p=0.003$ \\
\hline
\end{tabular}

${ }^{\mathrm{a} C P S}$ ChemoProphylaxis and Sporozoites immunization.

${ }^{b}$ HuHEP human hepatocytes.

${ }^{c} P f P$. falciparum.

dVol. volunteer.

eStatistics: significant difference between Post- and Pre-CPS IgG calculated using the non-parametric Mann-Whitney U-test.

stages of $P$. falciparum are induced in human volunteers that have undergone CPS-immunization.

The most striking result was that CPS-induced antibodies could strongly reduce the liver parasite load in human liver-chimeric mice, measured five days after infection by mosquito bite with $P$. falciparum sporozoites. This strong reduction in late stage liver infection (91.05\%) might be explained by CPS-induced antibodies targeting sporozoites either in the skin, in the circulation, or during liver infection and/or development. In rodent malaria models, it has been demonstrated that mice immunized by gamma-irradiated Plasmodium berghei-infected mosquito bites exhibited high levels of anti-sporozoite antibodies that immobilize sporozoites in the skin by inhibiting their gliding motility and ability to invade dermal blood vessels [64-66]. Therefore, CPS-induced antibodies might also limit the numbers of sporozoites injected into passively immunized mice and immobilizing 
the sporozoites in the mouse skin, thereby preventing their journey to the liver in the first place. However, the prolonged presence or trapping of sporozoites in the skin after mosquito bites has only been demonstrated in animal models of malaria and not in humans; this may be different for humans. To assess the effect of CPS-induced antibodies on sporozoite ejection during mosquito salivation and sporozoite motility in the skin, in vitro mosquito salivation assays [66] and in vivo intravital microscopy with Green-Fluorescent Protein-expressing P. falciparum parasites [64] can be used, respectively.

The overall liver parasite burden of the control mice (receiving pre-immunization IgG) was lower compared to previous studies $[58,61]$, likely due to mosquito and sporozoite batch variations. Another likely source of variation is the number of injected sporozoites between mice. Nevertheless, the obtained data were consistent across two independent experiments, and the data between two groups of mice receiving either pre- or postimmunization IgG were comparable. Finally, while mice injected with PBS could not be directly included in the IgG experiments due to limited availability of chimeric mouse numbers, PBS-injected mice used in other parallel experiments performed in the same time frame showed the same range in liver parasite burden as mice receiving pre-immunization IgG (Additional file 2).

In vitro sporozoite gliding was inhibited by postimmunization IgG in only $3 / 11$ volunteers. This low frequency may be due to the low concentration of IgG that had to be used because of limited supply $(2 \mathrm{mg} / \mathrm{ml}$, i.e. 2-5 fold lower than the typical concentration in human plasma). The high intra- and inter-assay variability, despite the fact that always the same operator was carrying out the experiments, may also have contributed to this outcome, which is possibly due to variation between sporozoite batches or methodological factors (e.g. the lack of a centrifugation step to settle sporozoites prior to gliding). Moreover, the manual readout by microscopy assessing shape or length of gliding trails remains somewhat subjective [67]. Overall, this assay appears more suitable for qualitative rather than quantitative analysis, e.g. for studying the phenotype of knock-out parasites [68,69].

The in vitro traversal assay, in contrast, is a highthroughput assay and the variation between replicate measurements is very tight (Additional file $1 \mathrm{~A}$ and $\mathrm{B}$ ). Although the percentage cells traversed varied between experiments (probably due to variation between sporozoite batches), incubation of sporozoites with $10 \mu \mathrm{g} / \mathrm{ml}$ of the anti-CSP monoclonal antibody (3SP2) consistently results in the same proportional traversal inhibition (median 86.4\%; IQR 85.0-89.7\%), independent of absolute traversal rates (Additional file 3). Moreover, the variability between duplicate/triplicate measurements for each IgG sample was very low. In contrast to the gliding assay, significant and consistent inhibition of traversal activity of sporozoites by CPS-induced antibodies was found, by as little as $1 \mathrm{mg} / \mathrm{ml}$ post-immunization IgG. For three of the volunteers whose IgG was assessed in this study, the protection status against mosquito-bite challenge remains unknown since they received a blood-stage challenge, but they did undergo the same immunization regimen as protected volunteers [46]. Consistent with this, their ability to reduce sporozoite traversal was comparable to that of volunteers known to be protected from mosquito challenge, and $2 / 3$ blood-stage challenged volunteers also showed inhibition of gliding motility.

A dose-dependency for the traversal inhibitory effect of CPS-induced IgG was observed, since traversal inhibition by $10 \mathrm{mg} / \mathrm{ml}$ IgG was about 2.2 fold higher than for $1 \mathrm{mg} / \mathrm{ml}$. Traversal inhibition showed a broad range across all volunteers. Possible reasons for this may be the intra-individual differences in antibody specificity, affinity maturation and/or binding capacity to sporozoites. Of note, inhibition of sporozoite traversal in vitro did not reach 100 percent, when using an average plasma concentration of $10 \mathrm{mg} / \mathrm{ml} \mathrm{IgG}$, and was lower than the inhibition of liver-stage infection and/or development in vivo. This might be due to the fact that antibodies do not only interfere with sporozoite hepatocyte traversal, but also with other mechanisms of sporozoite functionality. Another targeted pathway might be hepatocyte invasion, as shown for plasma from RAS- or CPS-immunized mice [36], and for serum, IgG, or monoclonal antibodies derived from human volunteers immunized by RAS [37-39], an irradiated and cryopreserved sporozoite vaccine [40], GAP ([43], or subunit vaccines $[61,70]$ - although it is not clear whether this process can be affected completely independently from traversal, which is a requirement for invasion [71]. Additionally, CPS-induced antibodies might also interfere with intrahepatic parasite development by inducing clearance of infected hepatocytes by means of antibody-dependent cell-mediated cytotoxicity, as shown in vitro in murine hepatic cells incubated with a monoclonal antibody recognizing Plasmodium heat shock protein 70 [72,73]. SCID mice, while devoid of adaptive lymphocytes, still have an innate immune system including natural killer (NK) cells and macrophages [74,75], both of which are capable of mediating antibody-dependent killing [76]. Whether such a mechanism may also play a role in the in vivo liver-chimeric $\mathrm{uPA}^{+/+}$-SCID model remains to be investigated.

Determining the antigen targets of CPS-induced functional antibodies will help to shed further light on the developmental stage at which the sporozoite/liver-stage is targeted. CSP and LSA-1 antigens have previously been demonstrated to be predominantly recognized by CPS-induced antibodies, as shown by microarray analysis of 809 P. falciparum antigens [48] and enzyme-linked 
immunosorbent assay and ELISpot analysis (Nahrendorf and Scholzen et al., manuscript in preparation). RTS,S vaccination has been shown to elicit antibody titers against only CSP and the highest anti-CSP antibody titers were found in protected volunteers $[18,20,21,25]$. Other studies, however, found that antibody responses to both CSP and TRAP did not differ between protected and unprotected RAS-immunized volunteers, but protected volunteers were able to recognize novel $P$. falciparum antigens $[77,78]$. Taken together, this suggests that reactivity of antibodies to pre-erythrocytic or cross-stage antigens other than CSP or TRAP may be associated with protective immunity and, therefore, analysis of plasma samples from (partially) protected CPS-immunized volunteers with a microarray containing $\sim 3,000 P$. falciparum genes is currently underway. This will be essential to identify novel pre-erythrocytic antigens that are associated with functional activity of CPS-induced antibodies and protective immunity.

Importantly, liver-stage infection in liver-chimeric $\mathrm{uPA}^{+/+}$-SCID mice was not completely blocked when using $10 \mathrm{mg} / \mathrm{ml} \mathrm{IgG} \mathrm{(which} \mathrm{is} \mathrm{equivalent} \mathrm{to} \mathrm{the} \mathrm{typical}$ IgG concentration in human plasma). This indicates that in CPS-immunized volunteers, other immune effector mechanisms may contribute to parasite elimination in concert with antibodies. CPS-induced antibodies may not fully prevent parasite infection, but may reduce the liver parasite load to such a extent, that T-cell mediated responses, for instance, might eliminate the residual infected hepatocytes and thus, prevent blood-stage infection, as observed in previous CPS-trials $[45,47]$.

\section{Conclusions}

In conclusion, CPS-induced antibodies have functional inhibitory activity against pre-erythrocytic stages of $P$. falciparum by inhibiting sporozoite traversal in vitro and infection of hepatocytes in vivo. These findings highlight the importance of functional antibodies in pre-erythrocytic immunity against malaria and are essential to the current understanding of the mechanisms involved in pre-erythrocytic immunity. Open questions based on these findings that will be addressed in future studies, include the specificity of CPS-induced antibodies and whether their functional activity correlates with CPSinduced protection against malaria.

\section{Additional files}

Additional file 1: Replicates from in vitro traversal experiments.

Replicates from traversal experiments conducted with either $1 \mathrm{mg} / \mathrm{ml}(\mathrm{A})$ or

$10 \mathrm{mg} / \mathrm{ml}(B)$ of pre- or post-immunization lgG from three pools of two volunteers (Study 1) or six individual volunteers (Study 2) are shown. Data are expressed as the mean percentage cells traversed \pm SD. Black squares and grey circles represent the percentage cells traversed by sporozoites incubated with either pre-immunization or post-immunization lgG, respectively. Filled symbols show volunteers protected against mosquito challenge. Open symbols represent volunteers with unknown protection status regarding mosquito challenge (blood-stage challenged).

Additional file 2: In vivo mosquito bite challenge experiments in human liver-chimeric mice. Data from human liver-chimeric mouse experiments conducted with $10 \mathrm{mg}$ of pre- or post-immunization IgG are shown. Mice injected with PBS could not be directly included in the lgG experiments due to limited availability of chimeric mouse numbers, however, PBS-injected mice used in other parallel experiments performed in the same time frame showed the same range in liver parasite burden as mice receiving pre-immunization lgG. Data are expressed as the median parasite load per million human hepatocytes \pm interquartile range.

Additional file 3: Sporozoites incubated with or without $10 \mu \mathrm{g} / \mathrm{ml}$ anti-CSP antibody. Data from 4 independent traversal experiments conducted with or without $10 \mu \mathrm{g} / \mathrm{ml}$ of monoclonal anti-CSP antibody are shown. (A) Data are expressed as the mean percentage cells traversed. Black circles and squares represent the percentage cells traversed by sporozoites incubated without or with $10 \mu \mathrm{g} / \mathrm{ml}$ anti-CSP antibody, respectively. (B) The percentage inhibition of traversal was calculated for sporozoites only compared to sporozoites incubated with $10 \mu \mathrm{g} / \mathrm{ml}$ anti-CSP antibody. Data are expressed as the median percentage traversal inhibition \pm interquartile range.

\section{Abbreviations}

CHMI: Controlled human malaria infection; CPS: ChemoProphylaxis and Sporozoites immunization; CSP: Circumsporozoite protein; FBS: Foetal bovine serum; GAP: Genetically attenuated parasites; IQR: Interquartile range; LSA-1: Liver-stage antigen 1; PBS: Phosphate buffered saline; $P f^{+}$: P. falciparum positive; PFA: Paraformaldehyde; PFGAP: P. falciparum genetically attenuated parasites; UPA: Urokinase-type plasminogen activator; RAS: Radiationattenuated sporozoites; RT: Room temperature; SCID: Severe combined immunodeficiency; TRAP: Thrombospondin-related adhesion protein.

\section{Competing interests}

The authors declare no competing interests.

\section{Authors' contributions}

MCB, LF, PM, GLR, CCH, AS and RWS conceived and designed the study. $M C B$ and LF carried out experiments. GJVG provided infected mosquitoes and sporozoites. MCB, LF, EMB, CCH, AS, RWS analysed and interpreted the data. MCB, CCH, AS and RWS wrote the manuscript, and EMB, LF, PM and GLR edited the manuscript. All authors read and approved the final manuscript.

\section{Acknowledgements}

We thank Meta Roestenberg, Matthew B.B. McCall and Guido J.H. Bastiaens for carrying out the two published clinical trials, Marga van de Vegte-Bolmer for parasite culture and Jolanda Klaassen, Laura Pelser-Posthumus, Jacqueline Kuhnen, Astrid Pouwelsen for technical assistance with breeding and generation of infected mosquitoes. We also would like to thank Lieven Verhoye for the generation of human liver-uPA ${ }^{+/+}-$SCID mice, and Will Roeffen and Theo Arens for technical assistance with lgG purifications.

This work was supported by grants provided from the Dioraphte Foundation, the European Sixth Framework Programme integrated project European Malaria Vaccine Development Association (EMVDA; Contract LSHP-CT-2007-037506), the FP7-founded European Virtual Institute of Malaria Research (EVIMalaR, grant agreement number 242095), Ghent University (GOA \#01G01712) and the Belgian State (IUAP P7/47-HEPRO2). LF is supported by a PhD grant of the Agency for Innovation by Science and Technology (IWT). MCB is supported by a Nijmegen Institute for Infection, Inflammation and Immunity (N4i) PhD scholarship. AS was supported by a long-term postdoctoral fellowship of the European Molecular Biology Organization (EMBO). The funders had no role in study design, data collection and analysis, decision to publish, or preparation of the manuscript.

\section{Author details}

${ }^{1}$ Radboud University Medical Center, Department of Medical Microbiology, Geert Grooteplein 28, Microbiology 268, Nijmegen, HB 6500, The Netherlands. ${ }^{2}$ Center for Vaccinology, Ghent University and University Hospital, De Pintelaan 185, Ghent 9000, Belgium. 
Received: 3 February 2014 Accepted: 26 March 2014

Published: 5 April 2014

\section{References}

1. Stewart MJ, Vanderberg JP: Malaria sporozoites leave behind trails of circumsporozoite protein during gliding motility. J Protozool 1988, 35:389-393.

2. Mota MM, Pradel G, Vanderberg JP, Hafalla JC, Frevert U, Nussenzweig RS, Nussenzweig $\mathrm{V}$, Rodriguez A: Migration of Plasmodium sporozoites through cells before infection. Science 2001, 291:141-144.

3. Amino R, Giovannini D, Thiberge S, Gueirard P, Boisson B, Dubremetz JF, Prevost MC, Ishino T, Yuda M, Menard R: Host cell traversal is important for progression of the malaria parasite through the dermis to the liver. Cell Host Microbe 2008, 3:88-96.

4. Stewart MJ, Nawrot RJ, Schulman S, Vanderberg JP: Plasmodium berghei sporozoite invasion is blocked in vitro by sporozoite-immobilizing antibodies. Infect Immun 1986, 51:859-864.

5. Sibley LD: Intracellular parasite invasion strategies. Science 2004, 304:248-253.

6. Ishino T, Yano K, Chinzei Y, Yuda M: Cell-passage activity is required for the malarial parasite to cross the liver sinusoidal cell layer. PLOS Biol 2004, 2:E4.

7. Tavares J, Formaglio P, Thiberge S, Mordelet E, Van Rooijen N, Medvinsky A, Menard R, Amino R: Role of host cell traversal by the malaria sporozoite during liver infection. J Exp Med 2013, 210:905-915.

8. Menard R, Tavares J, Cockburn I, Markus M, Zavala F, Amino R: Looking under the skin: the first steps in malarial infection and immunity. Nat Rev Microbiol 2013, 11:701-712.

9. Prudencio M, Rodriguez A, Mota MM: The silent path to thousands of merozoites: the Plasmodium liver stage. Nat Rev Microbiol 2006, 4:849-856.

10. Doolan DL, Dobano C, Baird JK: Acquired immunity to malaria. Clin Microbiol Rev 2009, 22:13-36.

11. Cohen S, McGregor IA, Carrington S: Gamma-globulin and acquired immunity to human malaria. Nature 1961, 192:733-737.

12. McGregor IA, Carrington SP, Cohen S: Treatment of East African P. falciparum malaria with West African human gamma-globulin. Trans R Soc Trop Med Hyg 1963, 57:170-175.

13. Sabchareon A, Burnouf $T$, Ouattara D, Attanath $P$, Bouharoun-Tayoun $H$, Chantavanich P, Foucault C, Chongsuphajaisiddhi T, Druilhe P: Parasitologic and clinical human response to immunoglobulin administration in falciparum malaria. Am J Trop Med Hyg 1991, 45:297-308.

14. Coggeshall LT, Kumm HW: Demonstration of passive immunity in experimental monkey malaria. J Exp Med 1937, 66:177-190.

15. Bruce-Chwatt LJ, Gibson FD: Transplacental passage of Plasmodium berghei and passive transfer of immunity in rats and mice. Trans $R$ Soc Trop Med Hyg 1956, 50:47-53.

16. Diggs $\mathrm{CL}$, Osler AG: Humoral immunity in rodent malaria. II. Inhibition of parasitemia by serum antibody. J Immunol 1969, 102:298-305.

17. Nussenzweig RS, Nussenzweig V: Development of sporozoite vaccines. Philos Trans R Soc Lond B Biol Sci 1984, 307:117-128.

18. Stoute JA, Slaoui M, Heppner DG, Momin P, Kester KE, Desmons P, Wellde BT, Garcon N, Krzych U, Marchand M: A preliminary evaluation of a recombinant circumsporozoite protein vaccine against Plasmodium falciparum malaria. RTS, S Malaria Vaccine Evaluation Group. N Engl J Med 1997, 336:86-91.

19. Kester KE, McKinney DA, Tornieporth N, Ockenhouse CF, Heppner DG Jr, Hall T, Wellde BT, White K, Sun P, Schwenk R, Krzych U, Delchambre M, Voss G, Dubois MC, Gasser RA Jr, Dowler MG, O'Brien M, Wittes J, Wirtz R, Cohen J, Ballou WR: Rts SMVEG: A phase I/lla safety, immunogenicity, and efficacy bridging randomized study of a two-dose regimen of liquid and lyophilized formulations of the candidate malaria vaccine RTS, S/AS02A in malaria-naive adults. Vaccine 2007, 25:5359-5366.

20. Kester KE, Cummings JF, Ockenhouse CF, Nielsen R, Hall BT, Gordon DM, Schwenk RJ, Krzych U, Holland CA, Richmond G, Dowler MG, Williams J, Wirtz RA, Tornieporth N, Vigneron L, Delchambre M, Demoitie MA, Ballou WR, Cohen J, Heppner DG Jr: Rts SMVEG: Phase 2a trial of 0, 1 , and 3 month and 0,7 , and 28 day immunization schedules of malaria vaccine RTS, S/AS02 in malaria-naive adults at the Walter Reed Army Institute of Research. Vaccine 2008, 26:2191-2202.
21. Kester KE, Cummings JF, Ofori-Anyinam O, Ockenhouse CF, Krzych U, Moris P, Schwenk R, Nielsen RA, Debebe Z, Pinelis E, Juompan L, Williams J, Dowler M, Stewart VA, Wirtz RA, Dubois MC, Lievens M, Cohen J, Ballou WR, Heppner DG Jr, Rts SVEG: Randomized, double-blind, phase 2a trial of falciparum malaria vaccines RTS, S/AS01B and RTS, S/AS02A in malaria-naive adults: safety, efficacy, and immunologic associates of protection. J Infect Dis 2009, 200:337-346.

22. Stoute JA, Kester KE, Krzych U, Wellde BT, Hall T, White K, Glenn G, Ockenhouse CF, Garcon N, Schwenk R, Lanar DE, Sun P, Momin P, Wirtz RA, Golenda C, Slaoui M, Wortmann G, Holland C, Dowler M, Cohen J, Ballou WR: Long-term efficacy and immune responses following immunization with the RTS, S malaria vaccine. J Infect Dis 1998, 178:1139-1144

23. Casares S, Brumeanu TD, Richie TL: The RTS, S malaria vaccine. Vaccine 2010, 28:4880-4894.

24. Rts SCTP, Agnandji ST, Lell B, Fernandes JF, Abossolo BP, Methogo BG, Kabwende AL, Adegnika AA, Mordmuller B, Issifou S, Kremsner PG, Sacarlal J, Aide P, Lanaspa M, Aponte JJ, Machevo S, Acacio S, Bulo H, Sigauque B, Macete E, Alonso P, Abdulla S, Salim N, Minja R, Mpina M, Ahmed S, Ali AM, Mtoro AT, Hamad AS, Mutani $P$, et al: A phase 3 trial of RTS, S/AS01 malaria vaccine in African infants. N Engl J Med 2012, 367:2284-2295.

25. White MT, Bejon P, Olotu A, Griffin JT, Riley EM, Kester KE, Ockenhouse CF, Ghani AC: The relationship between RTS, S vaccine-induced antibodies, CD4(+) T cell responses and protection against Plasmodium falciparum infection. PLoS One 2013, 8:e61395.

26. Olotu A, Fegan G, Wambua J, Nyangweso G, Awuondo KO, Leach A, Lievens M, Leboulleux D, Njuguna P, Peshu N, Marsh K, Bejon P: Four-year efficacy of RTS, S/AS01E and its interaction with malaria exposure. N Engl J Med 2013, 368:1111-1120.

27. Cowan G, Krishna S, Crisanti A, Robson K: Expression of thrombospondinrelated anonymous protein in Plasmodium falciparum sporozoites. Lancet 1992, 339:1412-1413.

28. Rogers WO, Malik A, Mellouk S, Nakamura K, Rogers MD, Szarfman A Gordon DM, Nussler AK, Aikawa M, Hoffman SL: Characterization of Plasmodium falciparum sporozoite surface protein 2. Proc Natl Acad Sci U S A 1992, 89:9176-9180.

29. Khusmith S, Charoenvit Y, Kumar S, Sedegah M, Beaudoin RL, Hoffman SL: Protection against malaria by vaccination with sporozoite surface protein 2 plus CS protein. Science 1991, 252:715-718.

30. Walsh DS, Pichyangkul S, Gettayacamin M, Tongtawe P, Siegrist CA, Hansukjariya P, Kester KE, Holland CA, Voss G, Cohen J, Stewart AV, Miller RS, Ballou WR, Heppner DG Jr: Safety and immunogenicity of rts, s + trap malaria vaccine, formulated in the AS02A adjuvant system, in infant rhesus monkeys. Am J Trop Med Hyg 2004, 70:499-509.

31. Cummings JF, Spring MD, Schwenk RJ, Ockenhouse CF, Kester KE, Polhemus ME, Walsh DS, Yoon IK, Prosperi C, Juompan LY, Lanar DE, Krzych U, Hall BT, Ware LA, Stewart VA, Williams J, Dowler M, Nielsen RK, Hillier CJ, Giersing BK, Dubovsky F, Malkin E, Tucker K, Dubois MC, Cohen JD, Ballou WR, Heppner DG Jr: Recombinant Liver Stage Antigen-1 (LSA-1) formulated with AS01 or AS02 is safe, elicits high titer antibody and induces IFN-gamma/IL-2 CD4+ T cells but does not protect against experimental Plasmodium falciparum infection. Vaccine 2010, 28:5135-5144.

32. Nussenzweig RS, Vanderberg J, Most H, Orton C: Protective immunity produced by the injection of $\mathrm{x}$-irradiated sporozoites of Plasmodium berghei. Nature 1967, 216:160-162.

33. Gwadz RW, Cochrane AH, Nussenzweig V, Nussenzweig RS: Preliminary studies on vaccination of rhesus monkeys with irradiated sporozoites of Plasmodium knowlesi and characterization of surface antigens of these parasites. Bull World Health Organ 1979, 57(Suppl 1):165-173.

34. Hoffman SL, Goh LM, Luke TC, Schneider I, Le TP, Doolan DL, Sacci J, de la Vega P, Dowler M, Paul C, Gordon DM, Stoute JA, Church LW, Sedegah M, Heppner DG, Ballou WR, Richie TL: Protection of humans against malaria by immunization with radiation-attenuated Plasmodium falciparum sporozoites. J Infect Dis 2002, 185:1155-1164.

35. Schofield L, Villaquiran J, Ferreira A, Schellekens $H$, Nussenzweig $R$, Nussenzweig $\vee$ : Gamma interferon, CD8+ T cells and antibodies required for immunity to malaria sporozoites. Nature 1987, 330:664-666.

36. Nganou-Makamdop K, Ploemen I, Behet M, Van Gemert GJ, Hermsen C, Roestenberg M, Sauerwein RW: Reduced Plasmodium berghei sporozoite liver load associates with low protective efficacy after intradermal immunization. Parasite Immunol 2012, 34:562-569. 
37. Hollingdale MR, Nardin EH, Tharavanij S, Schwartz AL, Nussenzweig RS: Inhibition of entry of Plasmodium falciparum and $P$. vivax sporozoites into cultured cells; an in vitro assay of protective antibodies. J Immunol 1984, 132:909-913.

38. Egan JE, Hoffman SL, Haynes JD, Sadoff JC, Schneider I, Grau GE, Hollingdale MR, Ballou WR, Gordon DM: Humoral immune responses in volunteers immunized with irradiated Plasmodium falciparum sporozoites. Am J Trop Med Hyg 1993, 49:166-173.

39. Herrington D, Davis J, Nardin E, Beier M, Cortese J, Eddy H, Losonsky G, Hollingdale M, Sztein M, Levine M, Nussenzweig R, Clyde DF, Edelman R: Successful immunization of humans with irradiated malaria sporozoites: humoral and cellular responses of the protected individuals. Am J Trop Med Hyg 1991, 45:539-547.

40. Seder RA, Chang LJ, Enama ME, Zephir KL, Sarwar UN, Gordon IJ, Holman LA, James ER, Billingsley PF, Gunasekera A, Richman A, Chakravarty S, Manoj A, Velmurugan S, Li M, Ruben AJ, Li T, Eappen AG, Stafford RE, Plummer SH, Hendel CS, Novik L, Costner PJ, Mendoza FH, Saunders JG, Nason MC, Richardson JH, Murphy J, Davidson SA, Richie TL, et al: Protection against malaria by intravenous immunization with a nonreplicating sporozoite vaccine. Science 2013, 341:1359-1365

41. Sack BK, Miller JL, Vaughan AM, Douglass A, Kaushansky A, Mikolajczak S, Coppi A, Gonzalez-Aseguinolaza G, Tsuji M, Zavala F, Sinnis P, Kappe SH: Model for in vivo assessment of humoral protection against malaria sporozoite challenge by passive transfer of monoclonal antibodies and immune serum. Infect Immun 2014, 82:808-817.

42. Spring M, Murphy J, Nielsen R, Dowler M, Bennett JW, Zarling S, Williams J, de la Vega P, Ware L, Komisar J, Polhemus M, Richie TL, Epstein J, Tamminga C, Chuang I, Richie N, O'Neil M, Heppner DG, Healer J, O'Neill M, Smithers H, Finney OC, Mikolajczak SA, Wang R, Cowman A, Ockenhouse C, Krzych U, Kappe SH: First-in-human evaluation of genetically attenuated Plasmodium falciparum sporozoites administered by bite of Anopheles mosquitoes to adult volunteers. Vaccine 2013, 31:4975-4983.

43. Finney OC, Keitany GJ, Smithers H, Kappe S, Wang R: Immunization with genetically attenuated $P$. falciparum parasites induces long-lived antibodies that efficiently block hepatocyte invasion by sporozoites. Vaccine 2014. doi: 10.1016/j.vaccine.2014.02.055. [Epub ahead of print].

44. Roestenberg M, McCall M, Hopman J, Wiersma J, Luty AJ, Van Gemert GJ, van de Vegte-Bolmer M, Van Schaijk B, Teelen K, Arens T, Spaarman L, De Mast Q, Roeffen W, Snounou G, Renia L, van der Ven A, Hermsen CC, Sauerwein R: Protection against a malaria challenge by sporozoite inoculation. N Engl J Med 2009, 361:468-477.

45. Roestenberg M, Teirlinck AC, McCall MB, Teelen K, Makamdop KN, Wiersma J, Arens T, Beckers P, Van Gemert G, van de Vegte-Bolmer M, van der Ven AJ, Luty AJ, Hermsen CC, Sauerwein RW: Long-term protection against malaria after experimental sporozoite inoculation: an open-label follow-up study. Lancet 2011, 377:1770-1776.

46. Bijker EM, Bastiaens GJ, Teirlinck AC, Van Gemert GJ, Graumans W, van de Vegte-Bolmer M, Siebelink-Stoter R, Arens T, Teelen K, Nahrendorf W, Remarque EJ, Roeffen W, Jansens A, Zimmerman D, Vos M, Van Schaijk BC, Wiersma J, van der Ven AJ, De Mast Q, Van Lieshout L, Verweij JJ, Hermsen CC, Scholzen A, Sauerwein RW: Protection against malaria after immunization by chloroquine prophylaxis and sporozoites is mediated by preerythrocytic immunity. Proc Natl Acad Sci U S A 2013, 110:7862-7867.

47. Teirlinck AC, McCall MB, Roestenberg M, Scholzen A, Woestenenk R, De Mast Q, van der Ven AJ, Hermsen CC, Luty AJ, Sauerwein RW: Longevity and composition of cellular immune responses following experimental Plasmodium falciparum malaria infection in humans. PLoS Pathog 2011 7:e1002389.

48. Felgner PL, Roestenberg M, Liang L, Hung C, Jain A, Pablo J, Nakajima-Sasaki R, Molina D, Teelen K, Hermsen CC, Sauerwein R: Pre-erythrocytic antibody profiles induced by controlled human malaria infections in healthy volunteers under chloroquine prophylaxis. Sci Rep 2013, 3:3549.

49. Ifediba T, Vanderberg JP: Complete in vitro maturation of Plasmodium falciparum gametocytes. Nature 1981, 294:364-366.

50. Ponnudurai $T$, Lensen $A H$, Leeuwenberg AD, Meuwissen $\mathrm{JH}$ : Cultivation of fertile Plasmodium falciparum gametocytes in semi-automated systems. 1. Static cultures. Trans R Soc Trop Med Hyg 1982, 76:812-818.

51. Ponnudurai $T$, Lensen AH, Meis JF, Meuwissen JH: Synchronization of Plasmodium falciparum gametocytes using an automated suspension culture system. Parasitology 1986, 93(Pt 2):263-274.
52. Ponnudurai $T$, Lensen $A H$, Van Gemert GJ, Bensink MP, Bolmer M, Meuwissen JH: Infectivity of cultured Plasmodium falciparum gametocytes to mosquitoes. Parasitology 1989, 98(Pt 2):165-173.

53. Nardin EH, Nussenzweig V, Nussenzweig RS, Collins WE, Harinasuta KT, Tapchaisri $P$, Chomcharn $Y$ : Circumsporozoite proteins of human malaria parasites Plasmodium falciparum and Plasmodium vivax. J Exp Med 1982, 156:20-30.

54. Prudencio $M$, Rodrigues $C D$, Ataide $R$, Mota $M M$ : Dissecting in vitro host cell infection by Plasmodium sporozoites using flow cytometry. Cell Microbiol 2008, 10:218-224.

55. Sattabongkot J, Yimamnuaychoke N, Leelaudomlipi S, Rasameesoraj M, Jenwithisuk R, Coleman RE, Udomsangpetch R, Cui L, Brewer TG: Establishment of a human hepatocyte line that supports in vitro development of the exo-erythrocytic stages of the malaria parasites Plasmodium falciparum and P. vivax. Am J Trop Med Hyg 2006, 74:708-715.

56. Sampath P, Pollard TD: Effects of cytochalasin, phalloidin, and $\mathrm{pH}$ on the elongation of actin filaments. Biochemistry 1991, 30:1973-1980.

57. Meuleman P, Libbrecht L, De Vos R, de Hemptinne B, Gevaert K, Vandekerckhove J, Roskams T, Leroux-Roels G: Morphological and biochemical characterization of a human liver in a UPA-SCID mouse chimera. Hepatology 2005, 41:847-856.

58. Foquet L, Hermsen CC, Van Gemert GJ, Libbrecht L, Sauerwein R, Meuleman P, Leroux-Roels G: Molecular detection and quantification of Plasmodium falciparum-infected human hepatocytes in chimeric immune-deficient mice. Malar J 2013, 12:430.

59. Leitner WW, Bergmann-Leitner ES, Angov E: Comparison of Plasmodium berghei challenge models for the evaluation of pre-erythrocytic malaria vaccines and their effect on perceived vaccine efficacy. Malar J 2010, 9:145.

60. Yoeli M, Upmanis RS, Vanderberg J, Most H: Life cycle and patterns of development of Plasmodium berghei in normal and experimental hosts. Mil Med 1966, 131(Suppl):900-914.

61. Foquet L, Hermsen CC, Van Gemert GJ, Van Braeckel E, Weening KE, Sauerwein R, Meuleman P, Leroux-Roels G: Vaccine-induced monoclonal antibodies targeting circumsporozoite protein prevent Plasmodium falciparum infection. J Clin Invest 2013, 124:140-144.

62. Hermsen CC, Telgt DS, Linders EH, van de Locht LA, Eling WM, Mensink EJ, Sauerwein RW: Detection of Plasmodium falciparum malaria parasites in vivo by real-time quantitative PCR. Mol Biochem Parasitol 2001, 118:247-251.

63. Alcoser SY, Kimmel DJ, Borgel SD, Carter JP, Dougherty KM, Hollingshead MG: Real-time PCR-based assay to quantify the relative amount of human and mouse tissue present in tumor xenografts. BMC Biotechnol 2011, 11:124.

64. Vanderberg JP, Frevert U: Intravital microscopy demonstrating antibody-mediated immobilisation of Plasmodium berghei sporozoites injected into skin by mosquitoes. Int J Parasitol 2004, 34:991-996.

65. Vanderberg J, Mueller AK, Heiss K, Goetz K, Matuschewski K, Deckert M, Schluter D: Assessment of antibody protection against malaria sporozoites must be done by mosquito injection of sporozoites. Am J Pathol 2007, 171:1405-1406. author reply 1406.

66. Kebaier C, Voza T, Vanderberg J: Kinetics of mosquito-injected Plasmodium sporozoites in mice: fewer sporozoites are injected into sporozoite-immunized mice. PLoS Pathog 2009, 5:e1000399.

67. Kaushansky A, Rezakhani N, Mann H, Kappe SH: Development of a quantitative flow cytometry-based assay to assess infection by Plasmodium falciparum sporozoites. Mol Biochem Parasitol 2012, 183:100-103.

68. Van Dijk MR, Douradinha B, Franke-Fayard B, Heussler V, Van Dooren MW, Van Schaijk B, Van Gemert GJ, Sauerwein RW, Mota MM, Waters AP, Janse CJ: Genetically attenuated, P36p-deficient malarial sporozoites induce protective immunity and apoptosis of infected liver cells. Proc Natl Acad Sci U S A 2005, 102:12194-12199.

69. Van Schaijk BC, Janse CJ, Van Gemert GJ, Van Dijk MR, Gego A, Franetich JF, van de Vegte-Bolmer M, Yalaoui S, Silvie O, Hoffman SL, Waters AP, Mazier D, Sauerwein RW, Khan SM: Gene disruption of Plasmodium falciparum p52 results in attenuation of malaria liver stage development in cultured primary human hepatocytes. PLoS One 2008, 3:e3549.

70. Hollingdale MR, Appiah A, Leland P, do Rosario VE, Mazier D, Pied S, Herrington DA, Chulay JD, Ballou WR, Derks T, Hiem Yap S, Beaudoin RL, Verhave JP: Activity of human volunteer sera to candidate Plasmodium 
falciparum circumsporozoite protein vaccines in the inhibition of sporozoite invasion assay of human hepatoma cells and hepatocytes. Trans R Soc Trop Med Hyg 1990, 84:325-329.

71. Mota MM, Hafalla JC, Rodriguez A: Migration through host cells activates Plasmodium sporozoites for infection. Nat Med 2002, 8:1318-1322.

72. Renia L, Mattei D, Goma J, Pied S, Dubois P, Miltgen F, Nussler A, Matile H, Menegaux F, Gentilini M, Mazier D: A malaria heat-shock-like determinant expressed on the infected hepatocyte surface is the target of antibody-dependent cell-mediated cytotoxic mechanisms by nonparenchymal liver cells. Eur J Immunol 1990, 20:1445-1449.

73. Mazier D, Renia L, Nussler A, Pied S, Marussig M, Goma J, Grillot D, Miltgen F, Drapier JC, Corradin G, Del Giudice G, Grau GE: Hepatic phase of malaria is the target of cellular mechanisms induced by the previous and the subsequent stages. A crucial role for liver nonparenchymal cells. Immunol Lett 1990, 25:65-70.

74. Dorshkind K, Keller GM, Phillips RA, Miller RG, Bosma GC, O'Toole M, Bosma MJ: Functional status of cells from lymphoid and myeloid tissues in mice with severe combined immunodeficiency disease. J Immunol 1984, 132:1804-1808.

75. Dorshkind K, Pollack SB, Bosma MJ, Phillips RA: Natural killer (NK) cells are present in mice with severe combined immunodeficiency (scid). J Immunol 1985, 134:3798-3801.

76. Graziano RF, Erbe DV, Fanger MW: The mechanisms of antibody-dependent killing mediated by lymphoid and myeloid cells are distinct based on different divalent cation requirements. J Immunol 1989, 143:3894-3900.

77. Doolan DL, Mu Y, Unal B, Sundaresh S, Hirst S, Valdez C, Randall A Molina D, Liang X, Freilich DA, Oloo JA, Blair PL, Aguiar JC, Baldi P, Davies DH, Felgner PL: Profiling humoral immune responses to P. falciparum infection with protein microarrays. Proteomics 2008, 8:4680-4694.

78. Trieu A, Kayala MA, Burk C, Molina DM, Freilich DA, Richie TL, Baldi P, Felgner $\mathrm{PL}$, Doolan DL: Sterile protective immunity to malaria is associated with a panel of novel P. falciparum antigens. Mol Cell Proteomics 2011, 10:M111 007948.

doi:10.1186/1475-2875-13-136

Cite this article as: Behet et al:: Sporozoite immunization of human volunteers under chemoprophylaxis induces functional antibodies against pre-erythrocytic stages of Plasmodium falciparum. Malaria Journal 2014 13:136.

\section{Submit your next manuscript to BioMed Central and take full advantage of:}

- Convenient online submission

- Thorough peer review

- No space constraints or color figure charges

- Immediate publication on acceptance

- Inclusion in PubMed, CAS, Scopus and Google Scholar

- Research which is freely available for redistribution 